\title{
ASSESSMENT OF HEMATOLOGICAL, BIOCHEMICAL AND OXIDATIVE STRESS PARAMETERS ON AGRICULTURAL PESTICIDES APPLICATION WORKERS IN EGYPT
}

\author{
[133] \\ Abdul-Aal ${ }^{\star}$ A.A.M., El-Zemaity M.S., Weshahy K. and Hammad M.A. \\ Plant Protection Dept., Fac. of Agric., Ain Shams Univ., P.O. Box 68, Hadayek Shoubra 11241, \\ Cairo, Egypt \\ *Corresponding author: Alyafifiy@agr.asu.edu.eg
}

Received 24 June, 2019

Accepted 7 July, 2019

\section{ABSTRACT}

The present study was carried out from November (2015) - October (2017) to determine the toxicological effects of pesticides exposure on agricultural application workers. Blood samples of the investigated workers were collected from Giza, Qalyubiyah and El-Buhayrah Governorates, Egypt. Thirty male individuals represented pesticide application workers were involved from the three governorates. Also, 25 male individuals (aged 18-55 years) were selected randomly from Cairo Governorate to represent the unexposed (control) group. Ten $\mathrm{ml}$ of blood sample per individual was collected and serological analysis for hematological (RBCs, TLC, Hb, PCV, MCV, $\mathrm{MCH}, \mathrm{MCHC}$ ), biochemical (ALT, AST, total protein, urea, creatinine and uric acid) and oxidative stress (GSH.R, MDA and $\mathrm{AChE}$ ) parameters were carried out. About $53 \%$ of workers involved was with an average level of education, between 18 and 35 years of age $(57 \%)$, working in their field for 6 to 10 years $(40 \%)$, about eight hours a day for six days a week on average $(67 \%) . \mathrm{Hb}, \mathrm{MCH}, \mathrm{MCHC}, \mathrm{ALT}, \mathrm{AST}$, AIP, TP, urea, creatinine and MDA were increased significantly by $5.58,9.23,3.75,55.49,42.44$, $30.07,6.83,49.33,25.48$, and $133.02 \%$ respectively. While the levels of Alb, GSH.R and AChE activity were significantly decreased by $14.51,8.33$ and $21.04 \%$ respectively. a significant positive correlation between exposure duration and ALT, AST, creatinine, urea and MDA. While, there were significant negative correlations between exposure duration and total protein, alkaline phosphatase, AChE Activity, GSH.R, RBCs, Hb, PCV, MCV and $\mathrm{MCH}$. Increasing of pesticide application workers vital parameters gives an indication of the occur- rence of various health consequences due to chronic exposure to pesticides. These results can be explained by the fact that the negligence of workers in following occupational safety and health measures from wearing protective tasks, not eating, drinking and smoking during the application of pesticides, resulting from the low awareness of workers about the risks of the materials dealt with and the decrease in their educational and cultural level increases the chances of exposure to the pesticide on the health of the worker.

Keywords: Pesticides application workers, hematological parameters, biochemical parameters, Pesticides exposure.

\section{INTRODUCTION}

Pesticides are highly used to protect agricultural crops from various pests (insects, fungus, nematodes, etc.) and reduce their harm and losses. The use of old and rickety equipment for the application of the pesticide with the lack of sufficient awareness of the path of optimal use, in addition to the decrease in the cultural and educational level of workers, in light of the deliberate negligence of workers in the use of certified prevention tasks (mask, gloves, shoes, clothing permeable pesticide) plays a pivotal role in Increase the harmful effect of pesticides on worker health. (Jallow et al 2017). As a result of the daily and excessive widespread use of pesticides, occupational exposure of a large number of the population to pesticides by different types and degrees of exposure (industrial, transport, storage, mix and application pesticides workers) has increased severely (Damalas and Koutroubas 2016). Occupational exposure to pesticides has many serious health complications. These health complications range from acute tox- 
icity that occurs immediately after exposure to several types of diseases (chronic inflammation, fibrosis and cancer) resulting in failure of one of the major vital organs (lungs, kidneys, heart, liver and nervous system) in his function (WHO, 1992; WHO, 1993). These health effects depend on several factors, including the method of exposure, the dose, the ability of the pesticide to enter the body, the rate of breakdown and removal of the pesticide in the body as well as the health of the person. (Nicolopoulou-Stamati et al 2016). Long term exposure to pesticides has been associated with hepatitis, cardiovascular disease, prostate cancer and thyroid function by many studies (IARC, 1991). Oxidative stress plays a major role in intoxication of pesticides including synthetic pyrethroid, organochlorine, carbamate and organophosphate. Exposure to pyrethroids and organophosphates have been linked to lipid peroxidation reactions. One of the most common markers of lipid peroxidation is malondialdehyde (MDA), formed as its product, which is often assayed with thiobarbituric acid (TBA) (Prakasam et al 2001).

Exposure to low concentrations of pesticides for long periods, occupationally or environmentally, may result in changes in hematological and biochemical indicators. Exposed farmers were found to have hemoglobin concentrations $(\mathrm{Hp})$, mean cell volumes (MCV), as well as higher mean corpuscular hemoglobin concentrations (MCHC). In addition, liver enzymes such as alkaline phosphatase (AIP), serum alanine aminotransferase (ALT), and aspartate aminotransferase (AST) were elevated in the exposed individuals compared to controls. Acetylcholinesterase $(\mathrm{AChE})$ is an integrated measure of the risk of neurotoxicity of organic environmental pollutants, including organophosphorus and carbamate pesticides These parameters may be used as early biomarkers for adverse effects (Manyilizu et al 2016).

The aim of the present work is determining the relationship between long-term to pesticides and potential health risks in male pesticide mixing and application workers in different governorates in Egypt using serum biochemical and hematological parameters and activity of esterase as exposure biomarkers.

\section{MATERIALS AND METHODS}

\section{- Experimental design}

Blood samples of the investigated agricultural pesticides application workers collected from dif- ferent governorates of Egypt: Giza, Qalyubiyah and El-Buhayrah Governorates. The Sample size included 30 workers aged between 18-55 years. Also, 25 male individuals almost the same age were selected randomly from Cairo governorate to represent unexposed or control group.

\section{- Blood sampling and processing}

Venous blood samples $(10 \mathrm{ml})$ were taken by venipuncture from each subject into vacationer contains anticoagulant ethylenediamine tetraacetic acid (EDTA) and vacationer contains a gel with density tubes from the exposed workers and controls. Serum samples were obtained by centrifugation at room temperature at $3000 \mathrm{rpm} / 5$ minutes. Serum samples were then used for biochemical analysis, while blood was used for hematological parameters, and oxidative stress parameters (Glutathione reductase and plasma malondialdehyde (MDA).

\section{- Analysis of Hematological parameters}

Hemoglobin $(\mathrm{Hb})$, red blood corpuscles (RBCs), packed cell volume (PCV), mean corpuscular volume (MCV), mean corpuscular hemoglobin $(\mathrm{MCH})$, mean corpuscular hemoglobin concentration (MCHC) and total leukocyte cell count (TLC) were carried out on Sysmex KX-21N automated hematology analyzer (Sysmex Corporation, Japan).

\section{- Biochemical analysis}

ALT and AST were determined by the International Federation of Clinical Chemistry (IFCC) methodology (Saris, 1978), AIP determined using the AACC and IFCC (Tietz, 1986), Urea was determined by using the enzymatic method of Talke and Schubert (1965), Serum creatinine was measured by a kinetic modification of the Jaffe (1886) procedure. Serum total protein was measured by the modification of Weichselbaum et al (1946) method. Acetylcholinesterase activity was determined by Ellman method (Ellman et al 1961).

\section{- Analysis of Oxidative stress parameters}

Glutathione reductase activity was assayed according to the method of Goldberg et al (1983). Plasma malondialdehyde (MDA) level measured by the method of Ohkawa et al (1979). 


\section{- Statistical analysis}

Data were computer analyzed using SAS 2005 statistical package. Analysis of Variance (ANOVA) test was employed to test the difference between groups (application workers and control). Regression analysis was performed to examine the differences in performance on the all biochemical and hematological tests administered to the group. The differences in biochemical and hematological parameters, and also between depressed and nondepressed AChE activity participants were analyzed using the Tuckey test.

\section{RESULTS}

Thirty pesticides-exposed agricultural workers and twenty-five unexposed controls were included in our study. About $53 \%$ with an average level of education, most of them are between 18 and 35 years of age (57\%), working in their field for 6 to 10 years (40\%), about eight hours a day for six days a week on average (67\%).

Hematological indices were changed in the exposed group, but it was not meaningful compared to the normal range. $\mathrm{Hb}, \mathrm{MCH}$ and $\mathrm{MCHC}$ were increased significantly by $5.58 \%, 9.23 \%$ and $3.75 \%$, respectively compared with the control group. However, there are no significant differences in other hematological parameters (Table 1).

Table 1. levels of hematological parameters in exposed workers in comparing with the control group

\begin{tabular}{|c|c|c|c|c|}
\hline Parameter & Reference Range & Un-exposed group & Exposed group & $\%$ Change \\
\hline $\mathrm{Hb}(\mathrm{g} / \mathrm{dl})$ & $13.2-17.3$ & $13.9 \pm 1.12$ & $14.7^{\star \star} \pm 0.92$ & 5.58 \\
$\mathrm{RBCs}\left(\mathrm{x} 10^{6} / \mathrm{ul}\right)$ & $4.3-5.7$ & $5.2 \pm 0.41$ & $5.03 \pm 0.41$ & -3.27 \\
$\mathrm{PCV}(\%)$ & $39.0-50.0$ & $41.8 \pm 3.23$ & $42.5 \pm 1.95$ & 1.72 \\
$\mathrm{MCV}(\mathrm{fl})$ & $80.0-100.0$ & $80.7 \pm 6.61$ & $85.0 \pm 6.03$ & 5.27 \\
$\mathrm{MCH}(\mathrm{pg})$ & $27.0-34.0$ & $26.8 \pm 2.46$ & $29.03^{* *} \pm 3.04$ & 9.23 \\
$\mathrm{MCHC}(\%)$ & $32.0-37.0$ & $33.2 \pm 0.66$ & $34.5^{* \star *} \pm 1.49$ & 3.75 \\
$\mathrm{TLC}\left(\mathrm{x} 10^{3} / \mathrm{ul}\right)$ & Up to 11.0 & $5.38 \pm 1.21$ & $5.44 \pm 1.77$ & 1.02 \\
\hline
\end{tabular}

* low significant; ${ }^{* *}$ Medium significant; ${ }^{* * *}$ highly significant, Hemoglobin (Hb), Red Blood Cells (RBCs), Packed Cell Volume (PCV), Mean Corpuscular Volume (MCV), Mean Corpuscular Hemoglobin (MCH), Mean Corpuscular Hemoglobin Concentration (MCHC), Grams Per Deciliter (g/dl), Percent (\%), Femtolitres (fl), Picograms (pg), Total leucocyte cell count (TLC).

Table (2) shows the levels of biochemical parameters (ALT, AST, AIP, TP, urea, creatinine and MDA) which increased significantly by 55.49 , 42.44, 30.07, 6.83, 49.33, 25.48, and 133.02\% respectively. While the levels of Alb, GSH.R and AChE activity were significantly decreased by $14.51,8.33$ and $21.04 \%$ respectively.
A significant positive correlation was shown between the working period and ALT, AST, creatinine, urea and MDA (0.858, 0.577, 0.539, 0.492 and 0.791 ). While there were significant negative correlations between exposure duration and alkaline phosphatase, AChE Activity, GSH.R, RBCs, $\mathrm{Hb}, \mathrm{PCV}$ and MCV $(0.178,0.472,0.502,0.122$, $0.122,0.122$ and 0.115$)$. On the other hand, there were significant correlations between exposure duration and $\mathrm{MCHC}$ and TLC (0.170 and 0.269). 
Table 2. Impact of pesticides exposure on biochemical and oxidative stress parameters in exposed workers group in comparing with the control group

\begin{tabular}{|c|c|c|c|c|}
\hline Group & Reference Range & Un-exposed group & Exposed group & $\%$ Change \\
\hline $\mathrm{ALT}(\mathrm{U} / \mathrm{ml})$ & Up to 45 & $27.2 \pm 5.88$ & $42.29^{* * *} \pm 3.38$ & 55.49 \\
\hline AST (U/ml) & Up to 42 & $28.1 \pm 6.3$ & $40.0^{* \star \star} \pm 5.54$ & 42.44 \\
\hline AIP $(U / L)$ & Up to 115 & $70.1 \pm 12.0$ & $91.20^{* * *} \pm 8.32$ & 30.07 \\
\hline $\operatorname{TP}(\mathrm{g} / \mathrm{dl})$ & $6.2-8.4$ & $7.18 \pm 0.63$ & $7.67^{\star \star \star} \pm 0.42$ & 6.83 \\
\hline Urea (mg/dl) & Up to 45 & $24.5 \pm 4.71$ & $36.6^{* \star \star} \pm 5.20$ & 49.33 \\
\hline Creatinine (mg/dl) & $0.5-1.2$ & $0.83 \pm 0.19$ & $1.04^{\star \star \star} \pm 0.15$ & 25.48 \\
\hline $\operatorname{MDA}(\mu \mathrm{mol} / \mathrm{L})$ & $1.8-5.7$ & $2.36 \pm 0.38$ & $5.49^{* \star \star} \pm 0.92$ & 133.02 \\
\hline AChE activity (U/L) & $>3500$ & $4740 \pm 502$ & $3743^{* * *} \pm 551$ & -21.04 \\
\hline $\begin{array}{l}\text { Erythrocytes GSH.R } \\
(\mathrm{gHb})\end{array}$ & $4.7-13.2$ & $7.2 \pm 0.8$ & $6.6^{\star \star \star} \pm 0.6$ & -8.33 \\
\hline
\end{tabular}

* low significant; ${ }^{* *}$ Medium significant; ${ }^{* * *}$ highly significant, Alanine Aminotransferase (ALT), Aspartate Aminotransferase (AST), Alkaline Phosphatase (ALP) Total protein (TP), malondialdehyde (MDA), Acetylcholinesterase (AChE), Glutathione Reductase (GSH.R), Unit per milliliter (U/ml), Unit per Liter (U/L), gram per deciliter $(\mathrm{g} / \mathrm{dl})$, milligram per deciliter $(\mathrm{mg} / \mathrm{dl})$, micromole per liter ( $\mu \mathrm{mol} / \mathrm{L})$, gram Hemoglobin.

\section{DISCUSSION}

The present study was conducted to evaluate the adverse effects of pesticides on some hematological and biochemical parameters in pesticides application workers chronically exposed to pesticides.

In undertaking the kind of study, we must consider the difficulty of assessment of the effect of exposure that may lead to chronic intoxication. The important points that have affected this study include the usage of various pesticides in combinations, commercially available or made by the workers themselves. Moreover, because of the impossibility of making the adjustment of dietary exposures between the study groups, the findings may be sometimes difficult to interpret. However, it is possible to draw conclusions about the overall health risk of pesticide exposure.

The observed significantly increased hematological parameters, $\mathrm{Hb}, \mathrm{MCH}$ and $\mathrm{MCHC}$ values in workers agree with the results reported in previous studies (Rentería et al $\mathbf{2 0 1 2}$ and Cortés et al 2017). These results can be explained by the fact that chronic exposure to pesticides causes chronic inflammation of bronchitis and the lungs may sometimes develop into asthma. Pneumonia causes chronic fibrosis in the lungs as a result of the death of alveoli epithelial cells (Mamane et al 2014). Which may cause the lungs to decrease their ability to exchange gases causing a decrease in oxygen concentration in blood, which stimulates the body to increase the production of hemoglobin to compensate for the lack of lung function. This effect increases with smokers because of the harmful effects of smoking on lung cells and increasing carbon monoxide in the blood, especially since most workers in the field are smoking heavily. (National Heart, Lung and Blood Institute 2018).

Among the analyzed serum enzymes, those reflecting hepatic damage (ALT, AST and ALP) were also significantly higher in workers compared with controls. These data might reflect subclinical hepatotoxic effects of pesticides. Our findings agree with the experimental and epidemiological studies reporting an increase in these enzymes after exposure to different kinds of pesticides. (Araoud et al 2012 and Patil et al 2003). Also, kidney functions parameters (creatinine and urea) were significantly elevated in workers compared with controls. This suggests that long term exposure to insecti- 

on Agricultural Pesticides Application Workers in Egypt

cides of high toxicity may disturb kidney functions resulting in elevated levels of kidney biomarkers in the blood serum (El-Nahhal et al 2016).

The results revealed a significant increase in the mean levels of serum total proteins of farm workers exposed to pesticides compared to controls. Serum protein concentrations may be altered due to the toxic effects of pesticides through impairment of protein synthesis by hepatocytes and disturbance of kidney function (Arafa et al 2013 and Mostafalou et al 2013).

Results indicate that chronic and multiple exposures to different complex mixture of pesticides suggest the accumulation of acetylcholine resulting in production of cholinergic effects and inhibition of red blood cell (RBC) AChE activity and significant inhibition of plasma cholinesterase in the sprayers could be due to the significant levels of pesticide residues in their blood/plasma as reported earlier (Khan et al 2008) and are in conformity with earlier reports (Safi et al 2005; Ismail et al 2010 and Issa et al 2010).

The increase in blood MDA (lipid peroxidation) is evident as subclinical oxidative stress in pesticides application workers. (Patil et al $\mathbf{2 0 0 3}$ and Fareed et al 2016).

\section{REFERENCES}

Arafa A., Afify M. and Nervana S. 2013. Evaluation of adverse health effects of pesticides exposure [biochemical and hormonal] among Egyptian farmers. J. Appl. Sci. Res. 9(7), 4404-4409.

Araoud M., Neffeti F., Douki W., Hfaiedh H.B., Akrout M., Hassine M., Najjar M.F. and Kenani A. 2012. Adverse effects of pesticides on biochemical and hematological parameters in Tunisian agricultural workers. J. Expo. Sci. Environ. Epidemiol., 22, 243-247.

Cortés S.C., Rodríguez A.I. and Suarez E.P. 2017. Assessment of hematological parameters in workers exposed to organophosphorus pesticides, carbamates and pyrethroids in Cundinamarca 2016-2017. Revista De Salud Pública, 19(4), 468-474.

Damalas C.A. and Koutroubas S.D. 2016. Farmers' Exposure to Pesticides: Toxicity Types and Ways of Prevention. Toxics, 4(1), 1-10.

Ellman G.L., Courtney K.D., Anders V. and Featherstone R.M. 1961. A new andrapid colorimetric determination of acetylcholinesterase activity. Biochem. Pharmacol. 7, 88-95.
El-Nahhal Y. 2016. Biochemical Changes Associated with Long Term Exposure to Pesticide among Farmers in the Gaza Strip. Occupational Diseases and Environmental Medicine, 4, 72-82.

Fareed M., Kesavachandran C.N., Bihari V., Kamal R. and Kuddus M. 2016. Oxidative stress and cholinesterase depression among farm workers occupationally exposed to pesticides in India. J. of Environmental Biology 38, 305-311.

Goldberg D.M. and Spooner R.J. 1983. In methods of enzymatic analysis (Bergmeyen, H.V. ed.) $3^{\text {rd }}$ Ed. Verlag Chemie, Weinheim, pp. 258-265.

International Federation of Clinical Chemistry IFCC 1986. Clinical Chemistry; J. Clinical Chemistry. Clin. Biochem. 24(7), 481-495.

International Agency for Research on Cancer IARC 1991. Occupational exposures in insecticide application and some pesticide, In IARC Monographs on the evaluation of the Carcinogenic Risk of Chemical to Human, 53, Lyon: IARC.

Ismail A.A., Rohlman D.S. and Abdel R.G.M. 2010. Clinical and Biochemical Parameters of Children and Adolescents Applying Pesticides. Int. J. Occup. Environ. Med. 3, 132-143.

Issa Y., Sham'a F.A., Nijem K., Bjertness E. and Kristensen P. 2010. Pesticide use and opportunities of exposure among farmers and their families: cross-sectional studies 1998-2006 from Hebron Governorate, occupied Palestinian territory. Environ. Health 63, 1-10.

Jaffé M. 1886. About the precipitate that picric acid produces in normal urine and about a new reaction of creatinine. Z. Physiol. Chem. 10, 391-400.

Jallow M.F.A., Awadh D.G., Albaho M.S., Devi V.Y. and Thomas B.M. 2017. Pesticide Knowledge and Safety Practices among Farm Workers in Kuwait: Results of a Survey. Int. J. of Environ. Res. and Public Health. 14(4), 340-355.

Khan D.A., Bhatti M.M., Khan F.A. and Naqvi S.T. 2008. Adverse effect of pesticides residues on biochemical markers in Pakistani tobacco farmers. Int. J. Clin. Exp. Med. 1, 274282.

Manyilizu W.B., Mdegela R.H., Kazwala R., Nonga H., Muller M., Lie E., Skjerve E. and Lyche J.L. 2016. Association of Long-Term Pesticide Exposure and Biologic Parameters in 
Female Farm Workers in Tanzania: A CrossSectional Study. Toxics, 4, 25-34.

Mostafalou S. and Abdollahi M. 2013. Pesticides and human chronic diseases: Evidences, mechanisms, and perspectives. Toxicol Appl Pharmacol. 268(2), 157-177.

Nicolopoulou-Stamati P., Maipas S., Kotampasi C., Stamatis P. and Hens L. 2016. Chemical Pesticides and Human Health: The Urgent Need for a New Concept in Agriculture. Frontiers in Public Health, 4, 148-156.

Ohkawa H., Ohishi N. and Yagi K. 1979. Assay for lipid peroxides in animal tissues by thiobarbituric acid reaction. Anal Biochem. 95, 351358.

Patil J.A., Patil A.J. and Govindwar S.P. 2003. Biochemical Effects of Various Pesticides on Sprayers of Grape Gardens. Indian J. of Clinical Biochemistry, 18(2), 16-22.

Prakasam A., Sethupathy S. and Lalitha S. 2001. Plasma and RBC antioxidant status in occupational male pesticide sprayers. Clin Chim. Acta. 310, 107-112.

Rentería R.P., Chávez G.G., Ascencio R.R., Martínez V.P., Islas L.M., Miranda C.B., Munguía S.M., Suárez L.J., Velasco A.F. and De Celis
R. 2012. Effect of Chronic Pesticide Exposure in Farm Workers of a Mexico Community, Archives of Environmental \& Occupational Health, 67(1), 22-30.

Safi J.M., Abu M.T.A. and Yassin M.M. 2005. Hematological biomarkers in farm workers exposed to organophosphorus pesticides in the Gaza Strip. Arch. Environ. Occup. Health 60(5), 235-241.

Saris N.E. 1978. Revised IFCC method for aspartate aminotransferase. Clin. Chem. 24, 720721.

Talke H. and Schubert G.E. 1965. Enzymatic Determination of Urea Using the Coupled Urease-GLDH Enzyme System. Mediators of Inflammation, 43, 174-176.

Tietz N.W. 1986. Textbook of Clinical Chemistry, W.B. Saunders, 1986.

Weichselbaum T.E. 1946. An accurate and rapid method for the determination of proteins in small amounts of blood serum and plasma. Am. J. Clin. Path 16, 40-49.

World Health Organisation 1993. In: IPCS. Methyl Parathion. Environmental health criteria, 145, WHO, Geneva. 
مجلة اتحاد الجامعات العربية للعلوم الزراعية ، جامعة عين شمس ، القاهرة ، مصر

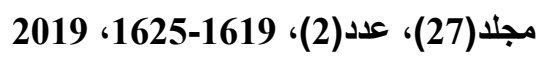

Website: http://ajs.journals.ekb.eg

تقييم المؤشرات الدموية والكيميائية الحيوية وقياسات الإجهاد التأكسدي

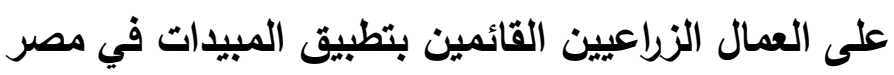

[133]

\begin{abstract}
علي عفيفي محمود عبد العال" - محمد السعيد الزميتي - قدري وشاحي - ماهر عبد العليم حماد قسم وقاية النبات - كلية الزراعة - جامعة عين شمس - ص.ب. 68 - حدائق شبرا 11241 - القاهرة - مصر مرئ

*Corresponding author: Alyafifiy@agr.asu.edu.eg
\end{abstract}

Received 24 June, 2019

Accepted 7 July, 2019

الكرياتينين و MDA بشكل كبير بمقدار 5.49، 5.58، 9.83، 9.23،

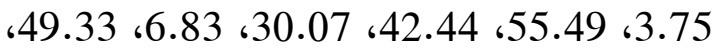

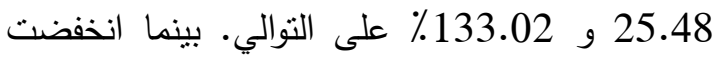
مستويات GSH.R, Alb و و

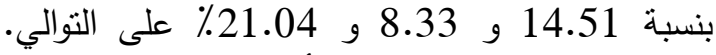
دلت النتائج المتحصل عليها أن هناك إرتباط معنوي

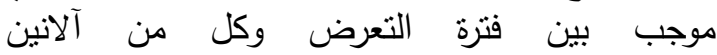

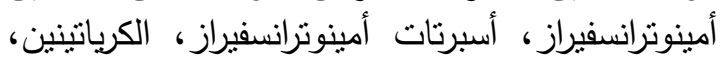

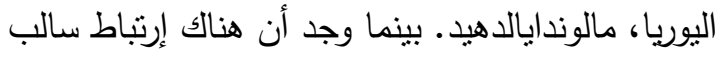

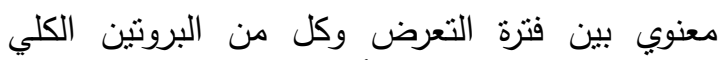
،الفوسفاتيز القلوي، نشاط أستيل كولين إستريز، الفرونين كرات

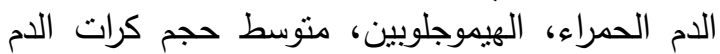
(MCV)

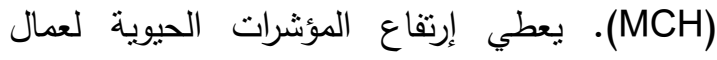

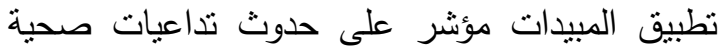

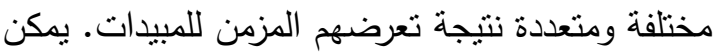
تقسير هذه النتائج على أن إهمال العمال في إنباع إنباع إنداء

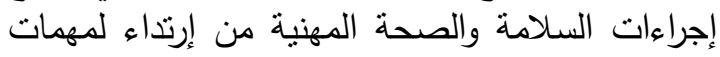

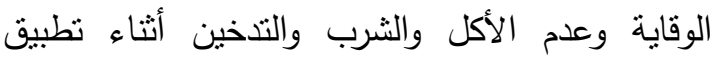

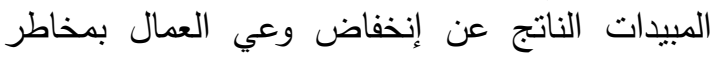

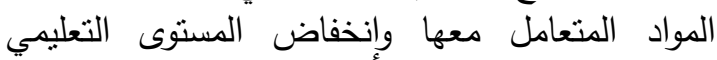

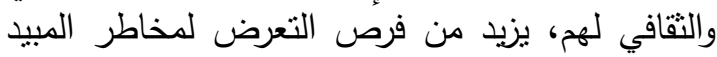

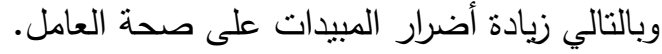

كلمات الدالة: عمال تطبيق المبيدات، مؤشرات دموية، مؤشرات حيوية، التعرض للمبيدات المبن

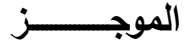

أجريت الدراسة الحالية في الفترة من نوفمبر 2017 - أكتوبر 2017 لتقدير التأثنرات التوكسيكولوجية نوفير التواتية

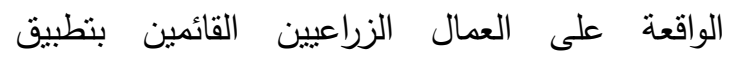

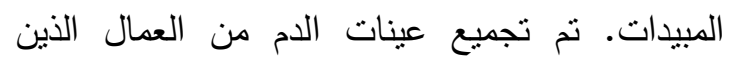

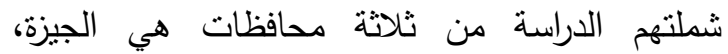

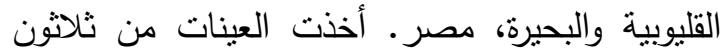
عامل (ذكر) يمنلون القائمين بتطبيق المبيدات في في المين

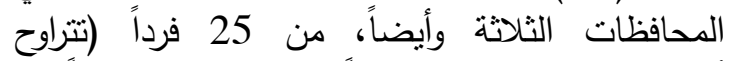

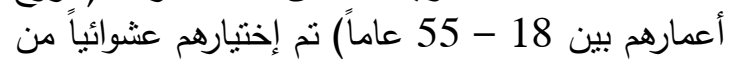
محافظة القاهرة كمجموعة مقارنة (غير الخير معرضين للمبيدات). أخذت عينات الدم بحجم 10 مل من كل كل من الذين تضمنتهم الدراسة، وأجرى عليها التحليل السيرولوجي للام (CBC)، المؤشرات الكيميائية الحيوية

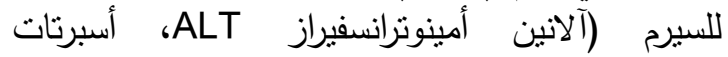

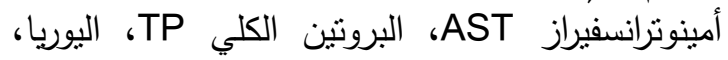
الكرياتينين، حمض اليوريك)، ونشاط إنزيمات الئرئن الإجهاد التأكسدي (جلوتاثيون أس - ترانسفيراز ، أسيتيل كولين الينين

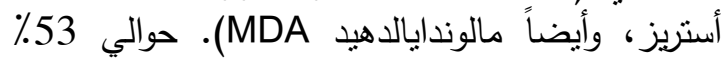

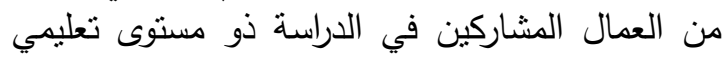
متوسط، أعمارهم تتراوح بين 18 و 35 سنة (57٪)،

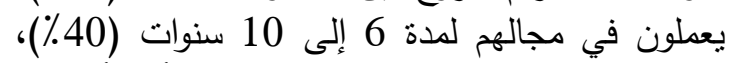
حوالي ثماني ساعات في اليوم لمدة ستة أيام أسبوعيا

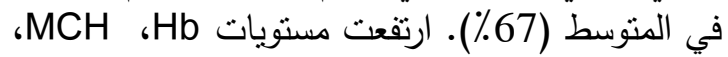
،AST، ALT ،MCHC 